\title{
Evaluation of Feather Meal in the Diet of Growing Rabbits
}

\section{Trigo María Soledad ${ }^{1,2}$, Muro María Gabriela ${ }^{1}$, Cattáneo Ana Carolina ${ }^{2}$, Arias Ruben Omar ${ }^{1}$, Cossu María Elena ${ }^{3}$, Antonini Alicia Graciela ${ }^{1,2}$}

\author{
${ }^{1}$ Curso de Introducción a la Producción Animal, Facultad de Ciencias Agrarias y Forestales, Universidad Nacional \\ de La Plata, 60 y 119, B1904AAO, La Plata, Argentina. \\ ${ }^{2}$ Instituto de Genética Veterinaria, Facultad de Ciencias Veterinarias, Universidad Nacional de La Plata, 60 y 118 , \\ B1904AAO, La Plata, Argentina \\ ${ }^{3}$ Departamento de Producción Animal, Facultad de Agronomía, Universidad de Buenos Aires, Av. San Martín 4453, \\ C1417DSE, Buenos Aires, Argentina
}

\begin{abstract}
The aim of this study was to evaluate the effect of an alternative protein source (hydrolyzed feather meal vs meat meal) and two levels (high:170 g and low:140 g CP) on performance and carcass quality traits in rabbits. One hundred twenty eight New Zealand x Californian rabbits were used, weaned at 28 days of age. The experimental design was a 2x2 factorial arrangement: two sources of animal protein (Control: MM and alternative: FM) and two levels of crude protein (CP: 17\% and 14\%). The digestibility of diets was evaluated based on 10 animals per treatment (between 49 and 56 days of age), using cages provided with individual faeces collectors. Daily weight gain (DWG), feed conversion ratio (FCR), dry matter digestibility (DMD), feed cost per rabbit and feed cost per $\mathrm{kg}$ of meat produced, were recorded. Forty animals (10 for each treatment) were slaughtered at 75 days of age, following the standard procedures of rabbit slaughter. Data were analyzed by ANOVA, GLM, SAS. The protein level of diet significantly influenced weights at 61 days, DMD, FCR and at slaughter, percentage of gastro-intestinal tract, weight of the stomach (full and empty), weight of the full caecum, hot carcass weight and carcass yield. The source of protein significantly influenced feed consumption, dry matter intake, feed conversion ratio, dressing percentage and feed cost per rabbit. Although the inclusion of FM in the diet did not generally affect performance traits, it did affect performance on the protein-restricted diets. The inclusion of feather meal in the diet appears to be the subject of the cost of this by-product when diet is formulated.
\end{abstract}

Keywords: Rabbits, Alternative Protein Source, Protein level, Performance

\section{Introduction}

Mineral pollution originated from animal production, especially from nitrogen and phosphorus in the excreta, has become a major problem in high density animal production systems. The reduction of excretions is directly related to the quality and quantity of the feed given. Improvement in the efficiency of nitrogen deposition can be obtained by matching the dietary amino acid composition with the animal's specific requirements. The bio-availability of commercial synthetic amino acids (AA) allows for the use of low protein diets. Metabolically, excess protein is used for energy purposes with a negative impact on the environment (Maertens, 1997).

Demand for quality sources of protein is likely to increase continuously in the future; this, can lead to an increased competition between humans and animals for quality sources of AA (Divakala, 2008). Alternative sources of protein for animal feed may be of plant or animal origin; these differ in their power values due to variations in nutrient content, palatability and handling property among other factors. Several factors such as economic feasibility, nutritive value, and environmental implications should be considered while choosing an appropriate alternative protein feedstuff.

One of the potential alternative protein sources for animal diets is the hydrolyzed feather meal (FM). According to Velazquez (1994), feathers accounted for $18.5 \%$ of the residues obtained from poultry slaughter. In Argentina, a net increase in annual poultry slaughter reached 722.119 .000 total birds in 2017 (Secretaría de Agroindustria, 2018). Although the slaughter decreased in the last year, it has been

This article is published under the terms of the Creative Commons Attribution License 4.0 Author(s) retain the copyright of this article. Publication rights with Alkhaer Publications.

Published at: http://www.ijsciences.com/pub/issue/2018-12/

DOI: 10.18483/ijSci.1855; Online ISSN: 2305-3925; Print ISSN: 2410-4477 
increasing since 2000 (348,384,000 heads), until 2015 (729,929,000 heads). Feather meal, generally contains 80 to $90 \%$ CP (Papadopoulos et al., 1985; Han and Parsons, 1991; Wang and Parsons, 1997; Ssu, 2004). However, due to their low levels of protein digestibility ( 5 to $26 \%$ ) they must be hydrolyzed for use in animal feed. (Blas et al, 2003; Coit et al, 2003.). There are different hydrolyzate methods that increase the digestibility of crude protein to values of $75-80 \%$ (Apple et al., 2003). Have no anti-nutritional factors, and, apparently, no risks of disease transmission. Thus, feather meal can be an attractive alternative protein source for rabbit diets.

There have been works including hydrolyzed feather feed in pigs (Divakala 2008; Heugten 2002; Apple et al. 2003). Ssu et al. (2004) showed that in the early stages of growth the hydrolyzate FM (3 and $9 \%$ of the diet) has negative effect on consumption, which a slow rate of growth, while in the fattening period did not affect performance traits.

The aim of this study was to evaluate the effect of an alternative protein source (hydrolyzed feather meal vs meat meal) and two levels (high:170 g and low:140 g $\mathrm{CP})$ on performance and carcass quality traits in rabbits.

\section{Materials and Methods}

The trial was conducted in the Experimental Field of Faculty of Agricultural and Forestry Sciences, National University of La Plata, Buenos Aires, Argentina.

\subsection{Diets, Animals and experimental design}

One hundred and twenty-eight New Zealand $\mathrm{x}$ Californian rabbits, weaned at 28 days of age, were used. Animals were randomly distributed into individual cages. The experimental design was a $2 \times 2$ factorial: two sources of animal protein $(\mathrm{MM}=$ meat meal as the control diet, and FM = hydrolyzed feather meal) and two levels of crude protein (according to the requirements established by Lebas, 1980, for rabbits in fattening period): $17 \%$ as control and $14 \%$ as an alternative due to the lower protein requirement in fattening. The nutritional value of the experimental diets is observed in table 1 . Food was supplied $a d$ libitum. Animals were weighed weekly using a scale with a sensitivity of 10 grams. The DM digestibility of diets was conducted using 10 animals (49 and 56 days of age)/treatment following the methodology proposed by Perez et al. (1996) using cages provided with individual faeces collectors. Performance traits: daily weight gain (ADG), feed conversion ratio (ICA), dry matter digestibility (DMD), feed cost per rabbit and feed cost per $\mathrm{kg}$ of meat produced were recorded. At 75 days of age, 40 rabbits (10/treatment) were slaughtered, following the scientific procedures of rabbit slaughter and carcass dissection proposed by Blasco and Ouhayoun (1996).

Tabla 1: Nutritional value of the experimental diets.

\begin{tabular}{lcccc}
\hline & D1 (MM17) & D2 (FM17) & D3 (MM14) & D4 (FM14) \\
DE (kcal/kg & 2754 & 2621 & 2694 & 2619 \\
MS) & & & & \\
DP (\%MS) & 71,9 & 71,7 & 72,2 & 72,2 \\
DP/DE (g/Mcal) & 44,0 & 46,2 & 37,4 & 37,7 \\
\hline
\end{tabular}

$\mathrm{DE}=$ Digestible energy. DP= Digestible protein. MM17= Meat meal, 17\% crude protein. FM17= Feather meal, $17 \%$ crude protein. MM14= Meat meal, 14\% crude protein. FM14= Feather meal, 14\% crude protein.

\subsection{Chemical Analyses}

Laboratory Analyses. Fecal samples were analyzed for dry matter (DM), and nitrogen (Kjeldahl-N, AOAC, 1995); crude protein (CP) was calculated Kjeldahl-N $(\%) \times 6.25$. All samples were analyzed for neutral detergent fiber (NDF) and acid detergent fiber (ADF) as described by Van Soest et al. (1991) modified by Komarek et al.(1994) for Ankom fiber determination (Ankom Technology, Fairport, Nueva York). The $\alpha$-amylase was used for NDF analysis in concentrate and feces samples.

\subsection{Statistical Analysis}

Collected data were analyzed by ANOVA using the GLM procedure of SAS (2004) for a factorial model (sources and levels of protein and their interaction).
Mean differences between treatments were compared using the Tukey test $(\mathrm{P}<0.05)$.

$$
Y i j=X+G i+P j+G i * P j+e i j
$$

where:

$\mathrm{Y}=$ dependent variable

$\mathrm{X}=$ mean

$\mathrm{Gi}=$ effect due to the protein level $(\mathrm{i}=1,2)$

$\mathrm{Pj}=$ effect due to the protein source $(\mathrm{j}=1,2)$

$\mathrm{e}=$ error associated

\section{Results and discussion}

Table 2 shows the effect of levels and sources of protein on rabbits weight from weaning to slaughter. There was no interaction, resulting in the effect of the 
protein level more important than the protein source for the parameters analyzed. Significant differences were observed in animal weight at 61 days old, resulting the heaviest animals with $17 \% \mathrm{CP}$. These differences were not observed in the slaughter weight (75 days of age).

Table 2: Level and source of protein effects on performance of fattening rabbits

\begin{tabular}{|c|c|c|c|c|c|c|c|c|}
\hline \multirow[t]{2}{*}{ Trait } & \multicolumn{2}{|c|}{ Source } & \multicolumn{2}{|c|}{ Protein level } & \multicolumn{3}{|c|}{ Prob. } & \multirow[t]{2}{*}{$\mathrm{SE}$} \\
\hline & $\mathrm{MM}$ & FM & $14 \%$ & $17 \%$ & Source & Level & $\begin{array}{c}\text { Source } \mathrm{x} \\
\text { Level }\end{array}$ & \\
\hline Weaning weight, 28 days (g) & 583 & 561 & 576 & 568 & 0,2311 & 0,6504 & 0,8303 & 13 \\
\hline Weight at 61 days (g) & 1861 & 1865 & 1826 & 1900 & 0,9224 & 0,0384 & 0,8306 & 25 \\
\hline Weight at slaughter, 75 days (g) & 2252 & 2251 & 2215 & 2287 & 0.9748 & 0.1125 & 0.3279 & 31 \\
\hline DWG (g) & 35,4 & 36,1 & 35,2 & 36,3 & 0.5056 & 0.2405 & 0.1868 & 0.6 \\
\hline
\end{tabular}

MM17= Meat meal, 17\% crude protein. FM17= Feather meal, 17\% crude protein. MM14= Meat meal, 14\% crude protein. FM14= Feather meal, 14\% crude protein. DWG= daily weight gain.

From comparing the regression lines of rabbit weights according to age, during the fattening period, significant differences could be observed among the slopes of diets $(\mathrm{P}=0.0101)$ (graph 1). However, slaughter weight (75 days) did not show significant differences for any of the two factors, source and protein level.

Graph 1: Comparison of regression lines of live weight of rabbits in fattening period

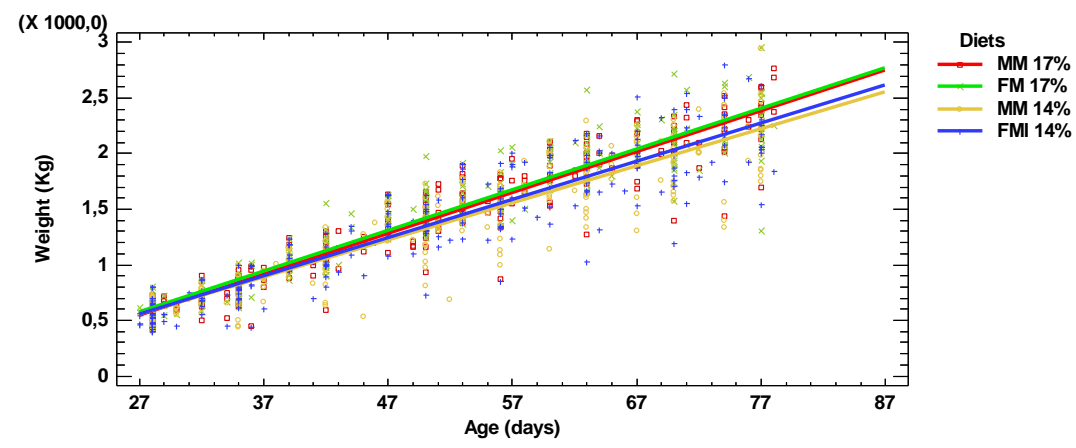

MM17= Meat meal, 17\% crude protein. FM17= Feather meal, $17 \%$ crude protein. MM14= Meat meal, $14 \%$ crude protein. FM14= Feather meal, 14\% crude protein.

For dry matter intake, only significant differences were observed $(\mathrm{p}=0.0096)$ for the 'protein source', with higher consumption in animals fed with hydrolyzed feather meal. For the feed conversion ratio (FCR), the significant differences were due to the 'protein level', with a lower value in those diets that contained a higher percentage of crude protein (Table 3).

Table 3: Level and source of protein effects on feed conversion index and dry mater intake (g/d)

\begin{tabular}{lcccccccc}
\hline \multirow{2}{*}{ Trait } & \multicolumn{2}{c}{ Source } & Protein level & & Prob. & SE \\
\cline { 2 - 8 } & MM & FM & $14 \%$ & $17 \%$ & Source & Level & $\begin{array}{c}\text { Source x } \\
\text { Level }\end{array}$ & \\
\hline FCR & 3,8 & 4.2 & 4.4 & 3,7 & 0.0659 & 0.0004 & 0.1609 & 0.1 \\
Dry matter intake (g/d) & 132,4 & 153,8 & 144,2 & 142,0 & 0,0096 & 0,7836 & 0,6452 & 5,5 \\
\hline
\end{tabular}

MM17= Meat meal, 17\% crude protein. FM17= Feather meal, 17\% crude protein. MM14= Meat meal, $14 \%$ crude protein. FM14= Feather meal, 14\% crude protein. $\mathrm{DWG}=$ daily weight gain. $\mathrm{FCR}=$ feed conversion ratio
Slaughter traits results are shown in Table 4. The protein level significantly influenced stomach weight (full and empty), full caecum weight, hot carcass weight, and carcass dressing percentage. The protein source only affected the dressing percentage, which was lower in the case of feather meal diets. 
Table 4: Effect of the level and source of protein on the carcass yield and quality traits

\begin{tabular}{|c|c|c|c|c|c|c|c|c|}
\hline \multirow[t]{2}{*}{ Trait } & \multicolumn{2}{|c|}{ Source } & \multicolumn{2}{|c|}{ Protein level } & \multicolumn{3}{|c|}{ Prob. } & \multirow[t]{2}{*}{$\mathrm{SE}$} \\
\hline & $\mathrm{MM}$ & FM & $14 \%$ & $17 \%$ & Source & Level & $\begin{array}{c}\text { Source } \mathrm{x} \\
\text { Level }\end{array}$ & \\
\hline Blood (\%LW) & 2.04 & 2.10 & 1.97 & 2.17 & 0.6180 & 0.1201 & 0.9928 & 0.1 \\
\hline Skin and feet (\%LW) & 18.5 & 18.1 & 18.2 & 18.4 & 0.2461 & 0.5669 & 0.1926 & 0.2 \\
\hline Full stomach (\%LW) & 5.2 & 5.3 & 5.7 & 4.8 & 0.4202 & 0.0002 & 0.9428 & 0.1 \\
\hline Empty stomach (\%LW) & 1.05 & 1.07 & 1.13 & 0.99 & 0.6548 & 0.0002 & 0.1225 & 0.02 \\
\hline Full caecum (\%LW) & 5.76 & 5.80 & 6.01 & 5.57 & 0.8314 & 0.0313 & 0.0576 & 0.1 \\
\hline Empty caecum (\%LW) & 1.58 & 1.53 & 1.56 & 1.55 & 0.5921 & 0.9615 & 0.1739 & 0.06 \\
\hline $\mathrm{pH}$ of caecum & 6.33 & 6.31 & 6.38 & 6.26 & 0.7397 & 0.0595 & 0.3256 & 0.04 \\
\hline Hot carcass weight $(\mathrm{g})$ & 1118 & 1102 & 1073 & 1147 & 0.4393 & 0.0010 & 0.6700 & 15 \\
\hline Dressing percentage $(\%)$ & 59.5 & 58.3 & 58.3 & 59.4 & 0.0287 & 0.0347 & 0.9248 & 0.3 \\
\hline
\end{tabular}

MM17= Meat meal, 17\% crude protein. FM17= Feather meal, 17\% crude protein. MM14= Meat meal, 14\% crude protein. FM14= Feather meal, 14\% crude protein.

Table 5 shows the results of in vivo digestibility of fiber and protein in fattening period (between 49 and 56 days of age). Significant differences were observed ( $\mathrm{p}<0.05)$ in dry matter digestibility (DMD), acid detergent fiber digestibility (ADFD) and crude protein digestibility (CPD) for the protein level, resulting in higher values of digestibility in diets with $17 \%$ protein. These differences in CPD did not correspond to a lower amount of $\mathrm{N}$ in faeces; diets of $14 \%$ has the lowest value $(\mathrm{p}=0.0004)$.

Table 5: Effect of the level and source of protein on digestibility traits

\begin{tabular}{|c|c|c|c|c|c|c|c|c|}
\hline \multirow[t]{2}{*}{ Trait } & \multicolumn{2}{|c|}{ Source } & \multicolumn{2}{|c|}{ Protein level } & \multicolumn{3}{|c|}{ Prob. } & \multirow[t]{2}{*}{$\mathrm{SE}$} \\
\hline & MM & FM & $14 \%$ & $17 \%$ & Source & Level & $\begin{array}{c}\text { Source } \mathrm{x} \\
\text { Level }\end{array}$ & \\
\hline DMD (\%) & 65,2 & 66.0 & 63,6 & 67.6 & 0.6077 & 0.0120 & 0.9013 & 1.1 \\
\hline CPD $(\%)$ & 88,8 & 89,0 & 87,9 & 89,8 & 0,7728 & 0,0083 & 0,6145 & 0,5 \\
\hline ADFD (\%) & 31.8 & 39,7 & 27,3 & 44.2 & 0.0123 & 0.0001 & 0.0053 & 2.1 \\
\hline NDFD (\%) & 44.5 & 47,4 & 44.7 & 47,1 & 0.2272 & 0.3200 & 0.4314 & 1.6 \\
\hline
\end{tabular}

MM17= Meat meal, 17\% crude protein. FM17= Feather meal, $17 \%$ crude protein. MM14= Meat meal, $14 \%$ crude protein. FM14= Feather meal, 14\% crude protein. $\mathrm{DMD}=$ dry matter digestibility. $\mathrm{CPD}=$ crude protein digestibility. $\mathrm{ADFD}=$ acid detergent fiber digestibility. $\mathrm{NDFD}=$ neutral detergent fiber digestibility

Table 6 shows the economic results for the two protein sources and two $\mathrm{CP}$ levels on growing rabbit performance. The protein level did not significantly influence the economic traits, while the source did result $(\mathrm{P}<0.10)$ in a slightly higher cost for feather meal-based diets.

Table 6: Effect of the level and source of protein on economic traits

\begin{tabular}{lcccccccc}
\hline \multirow{2}{*}{ Trait } & \multicolumn{2}{c}{ Source } & \multicolumn{2}{c}{ Protein level } & \multicolumn{3}{c}{ Prob. } & SE \\
\cline { 2 - 8 } & MM & FM & $14 \%$ & $17 \%$ & Source & Level & $\begin{array}{c}\text { Source x } \\
\text { Level }\end{array}$ \\
\hline Feed cost per rabbit $(\$)$ & 3.40 & 3.73 & 3.53 & 3.59 & 0.0105 & 0.6376 & 0.0980 & 0.9 \\
Feed cost per kg of meat $(\$)$ & 2.61 & 2.89 & 2.76 & 2.74 & 0.0516 & 0.8463 & 0.2860 & 0.1 \\
\hline
\end{tabular}

MM17= Meat meal, 17\% crude protein. FM17= Feather meal, 17\% crude protein. MM14= Meat meal, 14\% crude protein. FM14= Feather meal, 14\% crude protein. Feed cost (US\$/kg): MM17: 2.23; FM17: 2.22; MM14: 1.96; FM14: 1.97.

\section{Conclusions}

Although the inclusion of hydrolyzed feather meal did not affect performance traits, the economic results were not as expected due to higher feed intake levels, so the inclusion of feather meal in the diet appears to be subject of the cost of this by-product. Therefore the decision to use this alternative source will depend on its price when the diet is formulated.
The lower percentage of protein in the diet affected the performance traits. A lower total digestibility of diets with $14 \%$ crude protein could be due to the use of a more fibrous food resulting in a lower slaughter performance, due to a higher slaughter wastes incidence.

Although slaughter yield were lower in the proteinrestricted diets, a lower release of $\mathrm{N}$ in feces into the 
environment and a reduction in the costs of the feed were achieved, which could compensate for the lower productive performance.

\section{References}

1. Apple,J.K.; Boger, C. B.; Brow, D.C.; Maxwell,C.V.; Frieser, K.G. Roberts, W.J. and Jonson, Z.B. 2003. Effect of Feather meal on live animal performance and caecass quality and composition of growing-finishing. Swine. J.Anim.Sci. $81: 172$

2. Bauza R., Bratschi C., Gonzalez A., Hirigoyen A., Scaglia L., Sierra F. 2007. Evaluación de la inclusión de dos tipos dehidrolizado de plumas en dietas de cerdos en engorde. Sitio Argentino de Producción Animal. APPA - ALPA - Cusco, Perú, 2007.

3. Blasco A., Ouhayoun J. 1996. Harmonization of criteria and terminology in rabbit meat research. Revisal proposal. World Rabbit Science, 4 (2), 93-99.

4. Divakala K. C. 2008. Amino acid supplementation of hydrolyzed feather meal diets for finisher pigs. Auburn, $\begin{array}{llll}\text { Alabama } & \text { May } & 10, & \end{array}$ http://www.minagri.gob.ar/site/ganaderia/aves/01 Estadísticas/index.php. Febrero de 2012.

5. E van Heugten and T A T G van Kempen Growth performance, carcass characteristics, nutrient digestibility and fecal odorou compounds in growing-finishing pigs fed diets containing hydrolyzed feather meal. J. Anim. Sci. 2002 80:171-178

6. Maertens L., Luzy F., De Groote G. 1997. Effect of dietary protein and amino acids on the performance, carcass composition and $\mathrm{N}$-excretion of growing rabbits. Ann Zootech, 46, 255-268.

7. Ministerio de Agricultura. Buenos Aires, Argentina. http://www.minagri.gob.ar/site/ganaderia/aves/01-

Estadísticas/index.php. Febrero de 2014.

8. NRC 1977. Nutrient Requirements of Domestic Animals Nutrient Requirements of Rabbits. 2 nd revi. ed. ÑS y NRC, Washington DC. p. 14.

9. Perez J. M., Lebas F., Gidenne T., Maertens L., Villamide M. J., Carabaño R., Fraga M. J., Ramos M. A., Cervera C., Blas E., Fernandez J., Falcao E., Cunha L., Freire J., Xiccato G., Parigi Bini R., Dalle Zotte A., Cossu M. E., Carazzolo A., 1996. "Metodo Europeo di Riferimento per la Determinazione in Vivo della Digeribilità di Diete per Conigli". Zoot. Nutr. Anim., 22, 47-51.

10. SAS 2004. Institute Inc. SAS On line Doc* 9.1.3. Cary, NC: SAS Institute. Inc.

11. Ssu K. W., Brumm M. C., Miller P. S. 2004. Effect of feather meal on barrow performance. J. Anim. Sci. 82:25882595.

12. Velazquez C. 1994. Estudio de la disponibilidad y uso actual de productos y subproductos de origen animal en Uruguay. CONICYT

Uruguay.

21 